\title{
Whey proteins analysis in aqueous medium and in artificial gastric and intestinal fluids
}

\author{
Gildas K. GBASSI ${ }^{1 *}$, Fernand S. YOLOU ${ }^{1}$, Serigne O. SARR ${ }^{2}$, Patrick G. ATHEBA ${ }^{3}$, \\ Christophe N. AMIN ${ }^{1}$ and Michele AKE ${ }^{1}$ \\ ${ }^{I}$ Département de Chimie Analytique, Chimie Générale et Minérale, UFR Sciences Pharmaceutiques et \\ Biologiques, Université de Cocody, Abidjan, Cote d'Ivoire. \\ ${ }^{2}$ Laboratoire de Chimie Analytique, Faculté de Médecine, Pharmacie et Chirurgie Dentaire, \\ Université Cheick Anta Diop, Dakar, Sénégal. \\ ${ }^{3}$ Laboratoire de Chimie Physique, UFR Sciences des Structures, de la Matière et Technologie (SSMT), \\ Université de Cocody, Abidjan, Cote d'Ivoire. \\ *Corresponding author; E-mail: gildas.gbassi@laposte.net; \\ Tel.: (+225) 224722 17; Fax: (+225) 224441 71,
}

\begin{abstract}
Whey proteins isolates (WPI) were treated in aqueous medium at various $\mathrm{pH}$ values. Zeta potential, turbidity and particle size measurement were determined as a function of $\mathrm{pH}$. FTIR analysis was performed in ATR mode (attenuated total reflectance). Digestibility was assessed by treating whey proteins with artificial gastric and intestinal fluids. Proteolytic enzymes such as pepsin from porcine stomach mucosa was added in the gastric fluid. Pancreatin and trypsin from porcine and bile salts were added in the intestinal fluid. SDS-PAGE revealed hydrolysis of $\alpha$-lactalbumin and bovine serum albumin by pepsin while $\beta$-lactoglobulin was not hydrolyzed by gastric fluid. All the proteins of WPI were easily hydrolyzed in the intestinal fluid. The zeta potential of WPI went from positive values to negative values as the $\mathrm{pH}$ was increased. Turbidity values indicated the presence of particles in the solution which were confirmed by the measurement of particle size. FTIR analysis determined the fingerprint of WPI macromolecule.
\end{abstract}

(C) 2012 International Formulae Group. All rights reserved.

Keywords: WPI, Zeta potential, Turbidity, Particle size, FTIR-ATR, SDS-PAGE.

\section{INTRODUCTION}

Whey proteins, also known as serum proteins of milk by-products, are widely used in food products because of their high nutritional value and their ability to form gels, emulsions or foams (Lefevre and Subirade, $2000,2003)$. Whey is a general term that typically denotes the translucent liquid part of milk that remains following the process of coagulation and curd removal of cheese manufacturing (Geiser, 2003). From this liquid, whey proteins are separated and purified using various techniques yielding different concentrations of whey proteins. There are three main forms of whey proteins : whey powder (11 to $14.5 \%$ in protein), whey concentrate (25 to $89 \%$ in protein) and whey isolate ( $\geq 90 \%$ in protein) (Geiser, 2003). All 
of the constituents of whey proteins provide high levels of essential and branched chain amino acids. However, whey protein isolates (WPI) are the purest protein source available (Hoffman and Falvo, 2004). The composition of various proteins may be so unique that their influence on physiological function in the human body could be quite different. The quality of a protein is vital when considering the nutritional benefits that it can provide. Assessing the quality of a protein is determined by its essential amino acid composition and its digestibility in order to make these amino acids bioavailable in the gut (Hoffman and Falvo, 2004). Recently, studies highlighted opportunities to use whey proteins as vehicles for bioactive ingredients (Hebrard et al., 2006; Livney, 2010). These ingredients must be consumed orally and should therefore pass through the entire gastro-intestinal tract. Moreover whey proteins have potential as functional food ingredients for persons with obesity (Luhovy et al., 2007). However the effects described have been observed in shortterm experiments and when whey proteins are consumed in much higher amounts. Physicochemical conditions prevailing in the gastrointestinal tract such as $\mathrm{pH}$ changes may disrupt proteins stability ( $\mathrm{Yu}$ et al., 2002). Disruption of proteins stability may be desired depending on the area of bioactive ingredients issue such as stomach, small intestine or large intestine.

In this work were studied the behavior of whey protein isolates in aqueous solution and their digestibility in fluids simulating the stomach and the intestine milieus.

\section{MATERIALS AND METHODS}

Description of whey proteins and nutrient composition

Whey protein isolates (WPI, Bipro, Davisco $^{\circledR}$, Le Sueur, MN, USA) are white powder, odorless, semi-hygroscopic and insipid flavor. Total protein content obtained was $92.7 \%$ (total nitrogen determined by
Kjeldalh method, $\mathrm{N} \times 6.38$ ). Moisture and ash were respectively $5 \%$ and $2 \%$. Elemental analysis by X-Ray Fluorescence (X-Twin, Oxford $^{\circledR}$, Buchs, UK) revealed the following minerals: $\mathrm{Mg}(0.03 \%), \quad \mathrm{Ca} \quad(0.13 \%), \quad \mathrm{P}$ $(0.08 \%), \quad \mathrm{K} \quad(0.06 \%), \quad \mathrm{Na} \quad(0.60 \%), \quad \mathrm{Fe}$ $(0.005 \%)$.

\section{Preparation of whey proteins}

Diluted aqueous solutions of WPI $(0.1 \% \mathrm{w} / \mathrm{v})$ were prepared with milli-Q water (Millipore $^{\circledR}$, Strasbourg, France). Immersion of the $\mathrm{pH}$ electrode in the solution measured a $\mathrm{pH}$ value. Freshly prepared solutions of WPI had a pH of 7. Hydrochloric acid (Riedel de Haen $^{\circledR}$, Seelze, Germany) or sodium hydroxide (Panreac ${ }^{\circledR}$, Barcelona, Spain) was used to adjust the $\mathrm{pH}$ to the desired values.

\section{Zeta potential of whey proteins}

Electrophoretic mobility of WPI was performed using the Zetasizer Nano-ZS (Malvern ${ }^{\circledR}$, Worcestershire, UK) as previously described by Harnsilawat et al. (2007). The zeta potential measurement was carried out on the diluted solutions at various $\mathrm{pH}$ values $\mathrm{pH}$ 1, pH 2, pH 3, pH 4, pH 5, pH 6, pH 7 and $\mathrm{pH}$ 8). Using a syringe, $1 \mathrm{~mL}$ of the appropriate solution was introduced in the measurement vessel (special tank U-shaped). Vessel was positioned in the optical drive of the apparatus. Temperature was set at $25^{\circ} \mathrm{C}$ and voltage applied was $200 \mathrm{mV}$. Duration of analysis was approximately $10 \mathrm{~min}$.

\section{Particle size measurement of whey proteins}

The mean diameter of WPI in diluted aqueous solutions was determined as a fonction of $\mathrm{pH}$ with the Zetasizer Nano-ZS (Harnsilawat et al., 2007), an apparatus capable of measuring the dynamic light scattering using a helium-neon laser of output power of $4 \mathrm{~mW}$ operating at the fixed wavelength of $633 \mathrm{~nm}$ (wavelength of laser emission in the red). This apparatus can measure sizes from $1 \mathrm{~nm}$ to $10 \mu \mathrm{m}$. 


\section{Turbidity measurement of whey proteins}

Turbidity measurements were assessed using UV-Visible spectrophotometer (Model 2401PC, Shidmazu ${ }^{\circledR}$, Tokyo, Japan). Aliquots (1 mL) of WPI solution were introduced in a quartz cuvette and turbidity was measured at $600 \mathrm{~nm}$ in $1 \mathrm{~cm}$ path length optical cell against a blank of milli-Q water (Harnsilawat et al., 2007). At the wavelength of $600 \mathrm{~nm}$, proteins do not absorb light (Harnsilawat et al., 2007; Jones et al., 2010). According to Rayleigh-Debye theory (Erbil and Sarac, 2002; Xu et al., 2008), absorbance values measured can be converted to turbidity values according to the following equation:

$$
\tau=-\log T / L
$$

This theory showed a relationship between turbidity $(\tau)$ and transmittance $(\mathrm{T})$. L is the optical path length of the light beam and is expressed in centimeter $(\mathrm{cm})$. According to Beer-Lambert law, absorbance (A) can be written as follows:

$$
A=\log 1 / T
$$

The first equation can be written again as follows:

$$
\tau=\log A / L
$$

It is clear from this last equation that turbidity is proportional to absorbance and its unit is $\mathrm{cm}^{-1}$ because the optical path length is always expressed in $\mathrm{cm}$.

\section{FTIR analysis of whey proteins}

WPI were analyzed by infrared spectroscopy (FTIR, Nicolet 380, ThermoElectron $^{\circledR}$, Courtaboeuf, France) in ATR mode (attenuated total reflectance). A drop of the diluted solution of WPI at $\mathrm{pH} 7$ was directly deposited on the support (diamond crystal). A blank spectrum of diamond crystal was performed before samples spectral analysis. Samples spectra were recorded between 4000 and $500 \mathrm{~cm}^{-1}$. An average of 32 scans with a resolution equivalent to $4 \mathrm{~cm}^{-1}$ was performed on each sample.

\section{Digestibility of whey proteins Artificial media}

Simulation of gastric and intestinal media remains a major concern, all the experimental parameters are varied $(\mathrm{pH}$, incubation time, type of gastric and intestinal enzymes, etc.). No standard protocol is currently available. However, the parameters adopted in this work were described in a previous study (Gbassi et al., 2011). Briefly, the gastric fluid was saline solution $(\mathrm{pH} 1.8)$ containing pepsin from porcine mucosa (Sigma-Aldrich $^{\circledR}$, Steinheim, Germany). The intestinal fluid was saline solution $(\mathrm{pH}$ 7) containing pancreatin and trypsin from porcine pancreas (Sigma-Aldrich ${ }^{\circledR}$ ) plus bile salts (Fluka ${ }^{\circledR}$, Buchs, Switzerland).

\section{Digestibility in gastric fluid}

A volume of $50 \mathrm{~mL}$ of WPI solution was acidified $(\mathrm{pH} 1.8)$ with $3 \mathrm{~mol} / \mathrm{L}$ of hydrochloric acid. Another volume of $50 \mathrm{~mL}$ at $\mathrm{pH} 1.8$ contained $0.3 \%(\mathrm{w} / \mathrm{v})$ of pepsin. A control sample consisted of $50 \mathrm{~mL}$ of WPI solution at $\mathrm{pH} 7$. Each solution was incubated at $37^{\circ} \mathrm{C}$ during $4 \mathrm{~h}$, then mixed with $50 \mu \mathrm{L}$ of loading buffer to obtain $100 \mu \mathrm{L}$ of sample. The loading buffer consisted of $2.5 \mathrm{~mL}$ of pure glycerol $\left(\right.$ Fluka $\left.^{\circledR}\right), \quad 0.5 \mathrm{~mL}$ of 2mercaptoethanol $\left(\right.$ BioRad $^{\circledR}$, Hercules, CA, USA), $2 \mathrm{~mL}$ of an aqueous solution of SDS $\left(10 \% \mathrm{w} / \mathrm{v}, \mathrm{Bio}^{-\mathrm{Rad}^{\circledR}}\right), 1.25 \mathrm{~mL}$ of Tris-acid (0.5 mol/L, pH 6.8) (USB ${ }^{\circledR}$, Worcester, MA, USA), $0.2 \mathrm{~mL}$ of an aqueous solution of bromophenol blue $\left(0.5 \% \mathrm{w} / \mathrm{v}, \mathrm{Ems}^{\circledR}\right.$, Pasadena, CA, USA) and $3.55 \mathrm{~mL}$ of milli-Q water (Millipore ${ }^{\circledR}$ ). Gels preparation was the second step of handling. A single gel at $30 \%$ (w/v) was prepared by dissolving $29.2 \mathrm{~g}$ of acrylamide $\left(\mathrm{Bio}^{-\mathrm{Rad}^{\circledR}}{ }^{\circledR}\right)$ and $0.8 \mathrm{~g}$ of

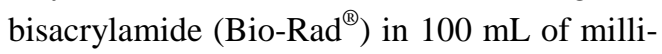
$\mathrm{Q}$ water. Two gels were prepared from the single gel. The first gel at $12 \%(\mathrm{v} / \mathrm{v})$ consisted of $4 \mathrm{~mL}$ of the single gel at $30 \%(\mathrm{w} / \mathrm{v}) ; 2.5$ $\mathrm{mL}$ of Tris-acid $(0.5 \mathrm{~mol} / \mathrm{L}, \mathrm{pH} 6.8), 0.1 \mathrm{~mL}$ of $\operatorname{SDS}(10 \%, \mathrm{w} / \mathrm{v})$ and $3.4 \mathrm{~mL}$ of milli-Q 
water. The second gel at $4 \%(\mathrm{v} / \mathrm{v})$ consisted of $1.3 \mathrm{~mL}$ of the single gel at $30 \%(\mathrm{w} / \mathrm{v}), 2.5 \mathrm{~mL}$ of Tris-acid (0.5 mol/L, pH 6.8), $0.1 \mathrm{~mL}$ of SDS (10\%, w/v) and $6.1 \mathrm{~mL}$ of milli-Q water. These gels were cast on the electrophoresis support (BioRad Mini Protean ${ }^{\circledR}$ II, $10 \mathrm{~cm} \times 8$ $\mathrm{cm})$. The first gel at $12 \%(\mathrm{v} / \mathrm{v})$ was a separating gel which has been cast to a height of about $6 \mathrm{~cm}$. The second gel at $4 \%(\mathrm{v} / \mathrm{v})$ called stacking gel was poured over the first on a height of about $2 \mathrm{~cm}$. A teflon comb deposited on the gel to strain was ten wells. The first well was reserved for the marker (reference proteins) and the other wells for samples. The electrophoresis support was placed in a tank containing the running buffer. The running buffer consisted of $3 \mathrm{~g} / \mathrm{L}$ of TrisBase (Sigma-Aldrich ${ }^{\circledR}$ ), $14.4 \mathrm{~g} / \mathrm{L}$ of glycine (Euromedex $^{\circledR}$, Mundolsheim, France) and 1 $\mathrm{g} / \mathrm{L}$ of SDS.

The samples filling was the last step of handling. A ten-fold dilution was performed (10 mL of sample plus $90 \mathrm{~mL}$ of milli-Q water). Diluted and undiluted samples were vortex-mixed and incubated in boiling water for $5 \mathrm{~min}$. $20 \mu \mathrm{L}$ of each sample was deposited in individual wells of the gel. A generator (Model $3000 \mathrm{Xi}$, BioRad ${ }^{\circledR}$ ) provided a voltage of $100 \mathrm{~V}$ for $15 \mathrm{~min}$ and $150 \mathrm{~V}$ for $45 \mathrm{~min}$. The migration was monitored by bromophenol blue indicating the migration front. Staining with colloidal Coomassie blue revealed the different fractions of whey proteins. At the end of electrophoresis, the gel was removed from the mold, fixed during 20 min and stained during $18 \mathrm{~h}$ under rotary agitation at $30 \mathrm{rpm} / \mathrm{min}$. The fixing solution consisted of a mixture of methanol $(45 \% \mathrm{v} / \mathrm{v}$, Sigma-Aldrich $\left.{ }^{\circledR}\right)$ and acetic acid $(1 \% \mathrm{v} / \mathrm{v}$, Fluka $\left.^{\circledR}\right)$. The staining solution consisted of methanol (34\% v/v), ammonium persulfate $\left(17 \% \mathrm{w} / \mathrm{v}, \mathrm{Bio}^{-\operatorname{Rad}^{\circledR}}\right)$, acetic acid $(1 \% \mathrm{v} / \mathrm{v})$ and coomassie blue G-250 (0.1\% w/v, Bio$\left.\operatorname{Rad}^{\circledR}\right)$. The gel was then washed with warm water $\left(35^{\circ} \mathrm{C}\right)$. Four washes of $20 \mathrm{~min}$ per wash have been sufficient to discolor the gel. Finally, the gel was scanned with a densitometer (GS-800, Bio-Rad ${ }^{\circledR}$ ).

\section{Digestibility in intestinal fluid}

A volume of $50 \mathrm{~mL}$ of WPI solution was acidified at $\mathrm{pH} 7$ after added pancreatin $(1 \% \mathrm{w} / \mathrm{v})$, trypsin $(1 \% \mathrm{w} / \mathrm{v})$ and bile salts $(0.3 \% \mathrm{w} / \mathrm{v})$. The different steps of in vitro digestibility described above have been performed: incubation of samples at $37{ }^{\circ} \mathrm{C}$ during $4 \mathrm{~h}$, mixing with loading buffer, gels preparation, samples dilution and filling, gel staining and gel scanning. About samples filling, a volume of $10 \mu \mathrm{L}$ has been deposited in the different wells of the gel.

\section{Statistical analysis}

All experiments were performed in triplicate and mean values along with their standard deviations were reported. Statistical significance of differences was determined using Student's $t$-test comparison procedure at a confidence level of $95 \%(p<0.05)$. The data were analyzed with the software Excel version 2003 (Window XP).

\section{RESULTS}

\section{Zeta potential of whey proteins}

The electrical charges of WPI were determined from their movement in an electrical field using an apparatus capable of microelectrophoresis. The results are reported in Figure 1.

The zeta potential of WPI went from positive values $(+9.5 \pm 0.2 \mathrm{mV})$ to negative values $(25.8 \pm 0.4 \mathrm{mV})$ as the $\mathrm{pH}$ was increasing from 1 to 8 . From $\mathrm{pH} 1$ to 4 , the zeta potential was positive. A significant difference was obtained between each value $(p>0.05)$. The zeta potential took a negative value at $\mathrm{pH} 5(-5.9 \pm 0.3 \mathrm{mV})$ and above. This value was significantly different from those obtained at $\mathrm{pH} 6,7$ and $8(p>0.05)$. 
However, no difference was observed in the values of the three latest $\mathrm{pH}(p<0.05)$. The zeta potential has taken a zero value between pH 4 and 5 corresponding to the isoelectric point of the protein which was estimated to be around $\mathrm{pH} 4.6$.

\section{Turbidity and particle size measurement of whey proteins}

The results of turbidity and particle size measurement are reported in Table 1 . Turbidity varies with the $\mathrm{pH}$ of the solution. Turbidity was near zero $\left(<7.10^{-3} \mathrm{~cm}^{-1}\right)$ to certain $\mathrm{pH}$ values $(\mathrm{pH} 1, \mathrm{pH} 2, \mathrm{pH} 3, \mathrm{pH} 6, \mathrm{pH}$ 7 and $\mathrm{pH} 8$ ). Values obtained at these $\mathrm{pH}$ were not statistically different $(p<0.05)$. However, turbidity values were $132 \pm 7\left(10^{-3} \mathrm{~cm}^{-1}\right)$ at $\mathrm{pH}$ 4 and $84 \pm 1\left(10^{-3} \mathrm{~cm}^{-1}\right)$ at $\mathrm{pH} 5$. A statistically significant difference was noted between these two values $(p>0.05)$ and with the values of other $\mathrm{pH}$. Concerning the particle size, the values obtained at $\mathrm{pH} 1$ and 2 were not significantly different $(p<0.05)$, similar to those obtained at pH 3 and $6(p<0.05)$ and at pH 7 and $8(p<0.05)$. However, a significant difference was noted at $\mathrm{pH} 4$ and $5(p>0.05)$.

\section{FTIR analysis of whey proteins}

FTIR-ATR spectrum of WPI was registered in the region of 4000 to $500 \mathrm{~cm}^{-1}$. The fingerprint of the macromolecule is shown in figure 2 and the relative position values of characteristic bands were described. The band at $3268.6 \mathrm{~cm}^{-1}$ corresponds to stretching vibrations of $-\mathrm{OH}$ linked to $-\mathrm{NH}_{2}$. The bands at $2961.5 \mathrm{~cm}^{-1}$ and $2926.6 \mathrm{~cm}^{-1}$ correspond to $-\mathrm{CH}_{2}$ groups. Bands between 2200 and $2000 \mathrm{~cm}^{-1}$ are due to diamond crystal absorption. The band at $1638.0 \mathrm{~cm}^{-1}$ is a characteristic band of primary amide group of proteins $\left(-\mathrm{CO}-\mathrm{NH}_{2}\right)$. The band at 1517.7 $\mathrm{cm}^{-1}$ is the secondary amide group of proteins (-CO-NH). The band at $1410.0 \mathrm{~cm}^{-1}$ and other bands around $1000 \mathrm{~cm}^{-1}$ correspond to $-\mathrm{C}-\mathrm{O}$, -
C-C and -C-OH groups. The bands at 1638.0 $\mathrm{cm}^{-1}$ and $1517.7 \mathrm{~cm}^{-1}$ are those that well characterize the whey proteins.

\section{Digestibility of whey proteins}

Figure 3 shows the results of WPI digestibility in simulated gastric environments. (M) is a reference sample consisting of nine proteins whose molecular weights are expressed in kilodalton (Kda). (A) represents the control sample consisting of WPI solution at $\mathrm{pH} 7$. (B) represents the WPI solution treated at $\mathrm{pH} 1.8$ and $(\mathrm{C})$ the WPI solution treated at $\mathrm{pH} 1.8$ in the presence of pepsin. (A'), (B') and (C') are the diluted samples of (A), (B) and (C). SDS-PAGE revealed that WPI contain three types of proteins (1, 2 and 3 ). The first protein of higher molecular weight is around $75 \mathrm{kDa}$. The second and the third protein are between 10 and $15 \mathrm{kDa}$. The second is near $15 \mathrm{kDa}$ while the third is near $10 \mathrm{kDa}$. Compared to control sample, no degradation has been observed while treating WPI at pH 1.8 (B and B'). However, the presence of pepsin ( $\mathrm{C}$ and C ') has degraded the protein of molecular weight around $75 \mathrm{kDa}$ and that near $10 \mathrm{kDa}$. Only the $15 \mathrm{kDa}$ protein has not been digested in the presence of pepsin.

Figure 4 shows the results of WPI digestibility in simulated intestinal environments. $\mathrm{M}$ and $\mathrm{A}$ are respectively the reference and the control samples. D and its diluted fraction (D') represent the WPI solution treated with an artificial intestinal fluid (saline solution at $\mathrm{pH} 7$ with pancreatin, trypsin plus bile salts). SDS-PAGE revealed a complete digestibility of WPI including betalactoglobulin in the artificial intestinal fluid after $4 \mathrm{~h}$ of incubation. 


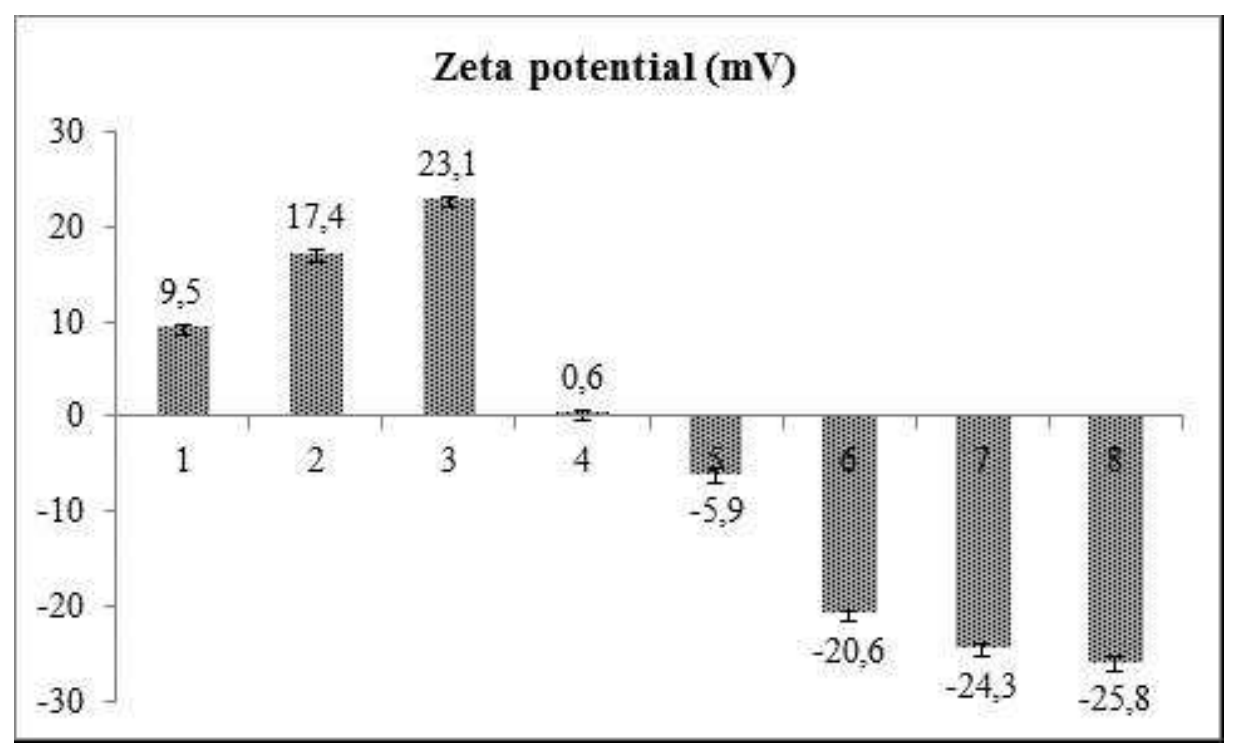

Figure 1: Zeta potential of whey protein isolates as a function of $\mathrm{pH}$. Data are means of three separate experiments with three measurements per experiment $(n=9)$. The error barrs represent standard deviations.

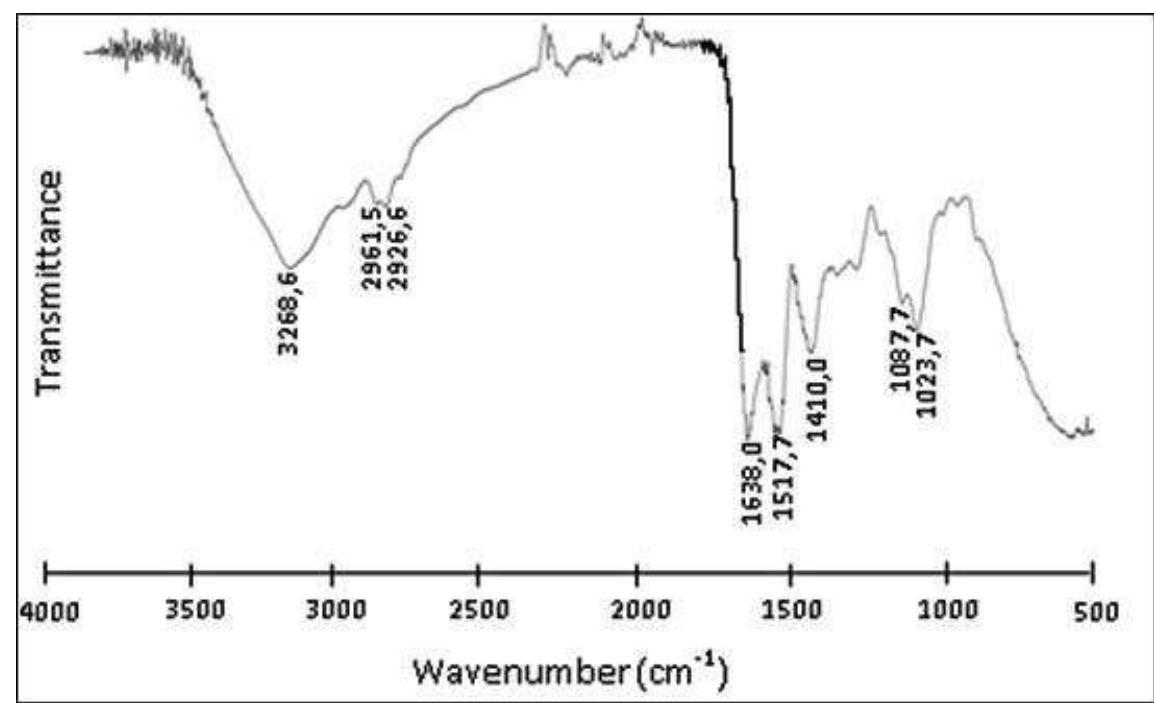

Figure 2: FTIR-ATR spectrum of whey protein isolates. 


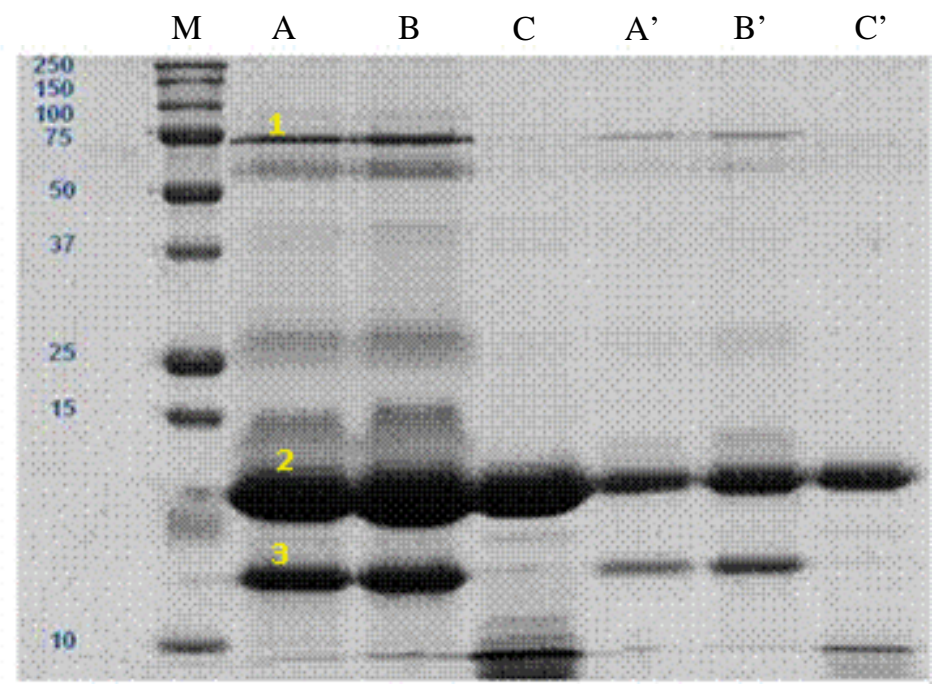

Figure 3: SDS-PAGE of WPI after artificial gastric treatment.

Sample filling volume: $20 \mu \mathrm{L}$, MW: molecular weight, M: reference proteins,

A: control sample $\mathrm{pH} 7, \mathrm{~B}$ : sample treated at $\mathrm{pH} 1.8, \mathrm{C}$ : sample treated at $\mathrm{pH} 1.8$ with pepsin;

A', B' and C' are the diluted solutions of A, B and C; 1, 2 and 3 are the products making up the WPI.

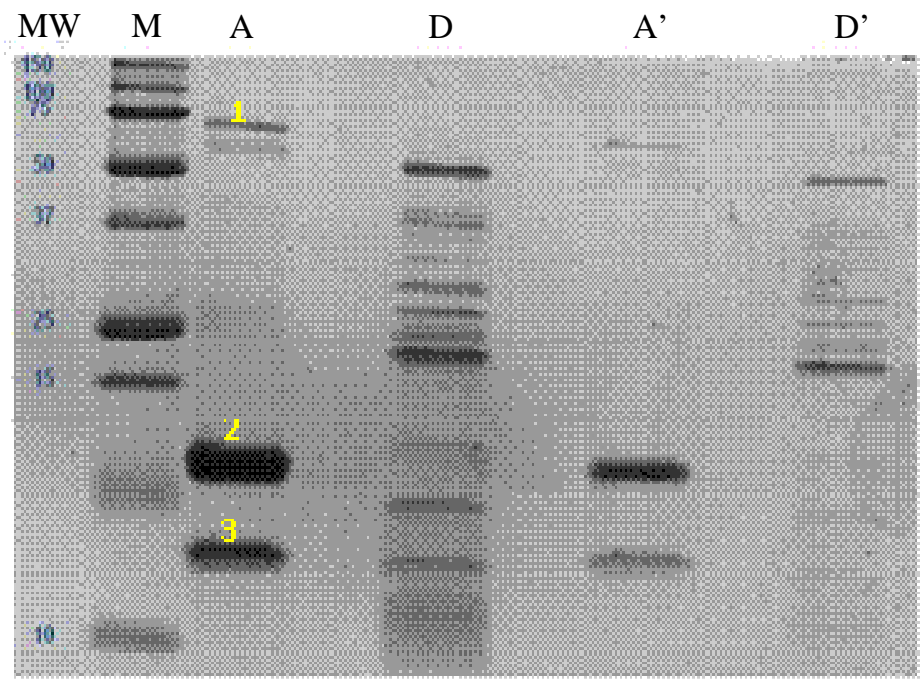

Figure 4: SDS-PAGE of WPI after artificial intestinal treatment. Sample filling volume: $10 \mu \mathrm{L}$, MW: molecular weight, M: reference proteins,

A: control sample $\mathrm{pH} 7$, D: sample treated at $\mathrm{pH} 7$ with pancreatin, trypsin and bile salts;

A' and D' are the diluted solutions of A and D, 1,2 and 3 are the products making up the WPI. 
Table 1: Turbidity and particle size measurement of WPI as a function of $\mathrm{pH}$.

\begin{tabular}{|c|c|c|}
\hline \multicolumn{3}{|c|}{ Whey proteins isolates (WPI) } \\
\hline & Turbidity $\left(\mathrm{cm}^{-1}\right) \times 10^{-3}$ & Particle size (nm) \\
\hline $\mathrm{pH} 1$ & $7 \pm 2^{a}$ & $58 \pm 10^{\mathrm{a}}$ \\
\hline $\mathrm{pH} 2$ & $1 \pm 2^{\mathrm{a}}$ & $47 \pm 8^{\mathrm{a}}$ \\
\hline $\mathrm{pH} 3$ & $2 \pm 0^{\mathrm{a}}$ & $168 \pm 12^{\mathrm{b}}$ \\
\hline pH 4 & $132 \pm 7^{b}$ & $295 \pm 39^{c}$ \\
\hline pH 5 & $84 \pm 1^{c}$ & $787 \pm 20^{\mathrm{d}}$ \\
\hline pH 6 & $4 \pm 0^{\mathrm{a}}$ & $194 \pm 22^{b}$ \\
\hline pH 7 & $4 \pm 0^{\mathrm{a}}$ & $106 \pm 10^{\mathrm{e}}$ \\
\hline $\mathrm{pH} 8$ & $2 \pm 0^{\mathrm{a}}$ & $101 \pm 7^{\mathrm{e}}$ \\
\hline
\end{tabular}

\section{DISCUSSION}

With regard to the results presented in Figure 1, it is clear that the zeta potential is influenced by the $\mathrm{pH}$ of the solution. In absolute value, a high zeta potential reflects the stability of the solution. In this case, WPI particles present in the solution tend to repel and cannot associate with each other (Le RoyBoehm and Fessi, 2000; Narong and James, 2006). Moreover, it is accepted that a value above $\pm 30 \mathrm{mV}$ means a high zeta potential (Terray, 2000). Theoretically the higher the zeta potential the better the interactions with oppositely charged compounds.

Turbidity which corresponds to a loss of the incident light due to the light scattering in the sample is proportional to the concentration of particles in the sample (Kleizen et al., 1995). Low turbidity indicates the presence of small amounts of particles in the solution. Turbidity values observed at $\mathrm{pH}$ 4 and 5 are due to particle aggregates present in the WPI solution. Attractive forces emerged around these $\mathrm{pH}$ values could generate aggregates. These forces may be attributed to hydrophobic attractive forces, electrostatic and van der Waals forces (Verheul et al., 1999). Only particle sizes below one micron are taken into account in the turbidity measurement as demonstrated by $\mathrm{Xu}$ et al. (2006). Table 1 also shows the influence of
$\mathrm{pH}$ on the WPI particle size. The lowest WPI particle sizes were observed at $\mathrm{pH} 7$ and 8 followed by pH 1 and 2. Size is an important parameter that affects stability and chemical reactivity of particles in solution. The lower the particles size in the solution the better the solubility of the solution (Gruy, 2011). When particles are of small sizes, the forces responsible for their dispersion in the solution outweigh those of gravitation, which keeps the solution homogeneous. In the case of solution mixtures, aggregates can form and make the solution inhomogeneous. Particle sizes have been described in the literature for some proteins, especially beta-lactoglobulin which showed a particle size between 200 and 500 $\mathrm{nm}$ at $\mathrm{pH} 4$ and 5 (Harnsilawat et al., 2006).

Figure 2 represents the fingerprint of WPI. According to Kher et al. (2007) a band around $1660 \mathrm{~cm}^{-1}$ or $1650 \mathrm{~cm}^{-1}$ characterize the primary amide region of whey proteins and another at $1630 \mathrm{~cm}^{-1}$ the secondary amide region. Similar bands have been observed in other types of proteins. Ribonuclease A, amyloid $\mathrm{P}$ component of human serum and egg white lysozyme showed bands corresponding to the region of the primary amide, respectively at $1689.0 \mathrm{~cm}^{-1}, 1687.0 \mathrm{~cm}^{-}$ ${ }^{1}$ and $1676.0 \mathrm{~cm}^{-1}$ (Hadden et al., 1995). In the region of secondary amide of these proteins were observed bands at $1548.0 \mathrm{~cm}^{-1}, 1558.0$ 
$\mathrm{cm}^{-1}$ and $1544.0 \mathrm{~cm}^{-1}$. The infrared spectrum being specific for a given structure.

Figures 3 and 4 represent the results of WPI digestibility. WPI components have been compared to literature data and the protein around $75 \mathrm{kDa}$ is bovine serum albumin, the second near $15 \mathrm{kDa}$ is beta-lactoglobulin and the third is alpha-lactalbumin (Perez et al., 2009). The results of this study support those of other authors who have highlighted the non-digestibility of beta-lactoglobulin in artificial gastric fluid (Kitabatake and Kinekawa, 1998; Li et al., 2004). However, this digestibility of WPI in intestinal fluid may be attributed to proteolytic enzymes that break peptide bonds of proteins. Kaur et al. (2010) showed a $45 \%$ loss of WPI stability after $2.5 \mathrm{~h}$ of incubation using an in vitro intestinal model containing pancreatin.

\section{Conclusion}

Zeta potential, turbidity, particle size, FTIR and SDS-PAGE provided information about WPI analysis. This study showed the influence of $\mathrm{pH}$ on zeta potential, turbidity and particle size of WPI. High values of zeta potential lead to electrically very charged solutions. Low values of turbidity lead to homogeneous solutions. However, aggregate particles have been formed near the WPI isoelectric point between $\mathrm{pH} 4$ and 5 . Digestibility of WPI varies with the nature of artificial fluid. Only beta-lactoglobulin has resisted to artificial gastric fluid. The knowledge obtained from this study could be used to rationally design food ingredients with specific functionalities. Such properties of WPI can be used in many fields, especially in encapsulation processes and controlled release systems. Loss of WPI stability during in vitro intestinal digestion could be used for food and pharmaceutical applications.

\section{REFERENCES}

Erbil C, Sarac AS. 2002. Description of the turbidity measurements near the phase transition temperature of poly(Nisopropyl acrylamide) copolymers: the effect of $\mathrm{pH}$, concentration, hydrophilic and hydrophobic content on the turbidity. Eur. Polym. J., 38: 1305-1310.

Gbassi KG, Vandamme T, Yolou FS, Marchioni E. 2011. In vitro effects of $\mathrm{pH}$, bile salts and enzymes on the release and viability of encapsulated Lactobacillus plantarum strains in a gastrointestinal tract model. Int. Dairy J., 21: 97-102.

Geiser M. 2003. The wonders of whey protein. NSCA's Perform. Train. J., 2: 1315.

Gruy F. 2011. Relationship between the morphology and the light scattering cross section of optically soft aggregates. $J$. Quant. Spectrosc. Rad. Transfer, 112(16): 2609-2618.

Hadden JM, Chapman D, Lee DC. 1995. A comparison of infrared spectra of proteins in solution and crystalline forms. Biochim. Biophys. Acta, 1248(2): 115122.

Harnsilawat T, Pongsawatmanit R, McClements DJ. 2006. Characterization of beta-lactoglobulin-sodium alginate interactions in aqueous solutions: a calorimetry, light scattering, electrophoretic mobility and solubility study. Food Hydrocolloids, 20: 577-585.

Hebrard G, Blanquet S, Beyssac E, Remondetto G, Subirade M, Alric M. 2006. Use of whey protein beads as a new carrier system for recombinant yeasts in human digestive tract. J. Biotechnol., 127: 151-160.

Hoffman JR, Falvo MJ. 2004. Protein-which is best? J. Sports Sci. Med., 3: 118-130.

Jones O, Decker EA, McClements DJ. 2010. Thermal analysis of bêta-lactoglobulin complexes with pectins or carrageenan for production of stable biopolymer particles. Food Hydrocolloids, 24(2-3): 239-248.

Kaur L, Rutherfurd SM, Mouqhan PJ, Drummond L, Boland MJ. 2010. Actinidin enhances protein digestion in the small intestine as assessed using an in 
vitro digestion model. J. Agric. Food Chem., 58(8): 5074-5080.

Kher A, Udabage P, McKinnon I, McNaughton D, Augustin MA. 2007. FTIR investigation of spray-dried milk protein concentrate powders. Vib. Spectrosc., 44(2): 375-381.

Kitabatake N, Kinekawa YI. 1998. Digestibility of bovine milk whey protein and bêta-lactoglobulin in vitro and in vivo. J. Agric. Food Chem., 46(12): $4917-$ 4923.

Kleizen HH, de Putter AB, van der Beek M, Huynink SJ. 1995. Particle concentration, size and turbidity. Filtr. Separat., 32(9): 897-901.

Lefevre T, Subirade M. 2000. Molecular differences in the formation and structure of fine-stranded and particulate bêtalactoglobulin gels. Biopolymers, 54: 578586.

Lefevre T, Subirade M. 2003. Formation of intermolecular bêta-sheet structures: a phenomenon relevant to protein film structure at oil-water interfaces of emulsions. J. Colloid Interface Sci., 263: 59-67.

Le Roy-Boehm AL, Fessi H. 2000. Applications pharmaceutiques du potentiel zêta: intérêt pour la caractérisation des vecteurs colloïdaux. $J$. Pharm. Belg., 55(2): 40-48.

Li Y, Dong J, Li J, Wang D. 2004. Stability of protein to digestion in vitro. J. Hyg. Res., 33(4): 433-437.

Livney YD. 2010. Milk proteins as vehicles for bioactives. Curr. Opin. Colloid Interface Sci., 15(1-2): 73-83.
Luhovy BL, Akhavan T, Anderson GH. 2007. Whey proteins in the regulation of food intake and satiety. J. Am. Coll. Nutr., 26(6): 704S-712S.

Narong P, James AE. 2006. Effect of pH on the zeta-potentiel and turbidity of yeast suspensions. Colloids Surf. A: Physicochem. Eng. Asp., 274: 130-137.

Perez AA, Carrara CR, Sanchez CC, Santiago LG, Rodriguez-Patino JM. 2009. Interfacial dynamic properties of whey protein concentrate/polysaccharide mixtures at neutral pH. Food Hydrocolloids, 23: 1253-1262.

TerrayM. 2000. Le potential zêta et la qualité des boissons: l'exemple du brassage de la bière. Liquid Conditionnem., 31(287): 1920.

Verheul M, Pedersen JS, Roefs SPFM, de Kruif KG. 1999. Association behaviour of native bêta-lactoglobulin. Biopolymers, 49: $11-20$.

Xu S, Liu J, Sun Z, Zhang P. 2006. A novel inverse method for determining the refractive indices of medium and dispersed particles simultaneously by turbidity measurement. J. Colloids Interface Sci., 326: 110-116.

$\mathrm{Xu} \mathrm{S}$, Liu J, Sun Z. 2008. Optical factors determined by the T-matrix method in turbidity measurement of absolute coagulation rate constants. J. Colloids Interface Sci., 304: 107-114.

Yu B, Lee TT, Chiou PW. 2002. Effects of sources of protein and enzyme supplementation on protein digestibility and chyme characteristics in broilers. $\mathrm{Br}$. Poultry Sci., 43(3): 424-431. 